\title{
Plataformas digitais e regulação trabalhista: precificação e controle do trabalhador neste novo modelo empresarial
}

\section{Digital platforms and labor regulation: pricing and worker control in this new business model}

\section{(iD) Murilo Carvalho Sampaio Oliveira ${ }^{1}$}

Resumo: Este texto discute a regulação do trabalho em plataformas digitais, a partir do resgate da ideia dependência econômica expressada pela precificação praticada. Inicia refletindo sobre tecnologia, a concepção da natureza cultural desta, as questões contemporâneas dos algoritmos e a produção massiva de dados. Adiante, investiga os caracteres e tipologias das plataformas digitais de trabalho como o novo modelo tecnológico de organização do trabalho em ascensão, ressaltando o contraste entre a sua eficiência econômica e a precariedade das condições concretas de trabalho daqueles sujeitos classificados como parceiros autônomos. Em seguida, demonstra-se a aplicabilidade da regulação do Direito do Trabalho para plataformas digitais classificadas como dirigentes, especificamente pela retomada do critério da dependência econômica mediante o método da precificação, inclusive percorrendo as críticas a tal conceito e seu uso em algumas decisões judiciais. Durante todo o texto, os exemplos dados estão ancorados a partir da empresa Uber, como estudo de caso concreto. Valendo-se do método dialético e de uma abordagem transdisciplinar de caráter sociojurídica-crítica, foram manejadas técnicas de pesquisa bibliográfica e documental sobre

\footnotetext{
1 Juiz do Trabalho na Bahia e Professor Associado da UFBA em Direito e Processo do Trabalho. Graduado, Especialista e Mestre em Direito pela UFBA e Doutor pela UFPR, além de especialização em relações laborais pela Universidad de Castilla-La Mancha na Espanha. Estágio Pós-doutoral na UFRJ. Pesquisador na área de Direito do Trabalho, atuando principalmente nos seguintes temas: dependência econômica, subordinação jurídica e execução trabalhista. Integrante do Grupo de Pesquisa Transformações do Trabalho, Democracia e Proteção Social (TTDPS), filiado à Rede Nacional de Pesquisas e Estudos em Direito do Trabalho e da Seguridade Social (RENAPEDTS).
} 
julgados. Nas conclusões, apresenta-se uma reflexão crítica sobre as questões semânticas e seus usos ideológicos, indicando a necessidade urgente de regulação do trabalho em plataformas digitais.

Palavras-chave: Plataformas digitais de trabalho. Salário por peça. Dependência econômica. Proteção Trabalhista.

\begin{abstract}
This work discusses the labor regulation in digital platforms, as of recovering the idea of expressing economic dependence through the pricing performed in such business model. The starting point was reflecting on concept of the historical and cultural natures of technology and contemporary questions regarding the algorithms and mass production of data. Further on, the characteristics and typologies of digital labor platforms were investigated as a new and rising technologic model of work organization, emphasizing the contrast between this activity's economic efficiency and the precariousness of the actual working conditions of those individuals/subjects classified as partners and self-employed. Then, it was demonstrated that Labor Law regulation is applicable to those digital platforms categorized as controlling/leading, specifically by reconsidering the criterion of economic dependence as the method of pricing, including the existing criticism on said concept and its use applied in judicial decisions. Throughout the text, the examples used are based on the company Uber, as case studies. Using the dialectical method and a multidisciplinary, socio-juridic and critical approach, there were conducted bibliographic and documental research techniques. By way of conclusion, a critical reflection on the semantical questions and their ideological uses is presented, indicating an urgent need to regulate work in digital platforms.
\end{abstract}

Key-words: Digital labor platforms. Piece-rate wage. Economic dependence. Labor protection.

Data de submissão do artigo: Março de 2021

Data de aceite do artigo: Junho de 2021 
Plataformas digitais e regulação trabalhista: precificação e controle do trabalhador neste novo... Murilo Carvalho Sampaio Oliveira

\section{Introdução}

Este artigo científico sintetiza estudos sobre a regulação jurídica laboral incidente nas plataformas digitais de trabalho. Na busca por modelos regulatórios compromissários da proteção social, foram examinadas, de modo crítico e interdisciplinar, a organização e funcionamento das chamadas plataformas digitais de trabalho como modelo empresarial, as condições concretas de trabalho nesses ambientes e aplicabilidade da categoria jurídica da dependência econômica como critério adequado à caracterização do vínculo empregatício.

A partir do método dialético e numa abordagem transdisciplinar, notadamente de caráter sociojurídica-crítica que problematiza a realidade social e a forma jurídica-normativa (FONSECA, 2009, p. 52-55), foram manejadas técnicas de pesquisa bibliográfica e documental sobre julgados, com predominância de leituras e fichamentos de artigos de periódicos e publicações especializadas. Com o intuito de não reproduzir e legitimar estrangeirismos, os termos de outras línguas - muito frequentes nos debates tecnológicos ("tech") - foram primeiro mencionados no vernáculo e depois na expressão inglesa ou estrangeira correspondente.

A diretriz deste episteme crítica metodológica guiou a percepção da realidade do trabalho organizado em modelos de gestão altamente tecnológicos na perspectiva da totalidade. Afastou-se, assim, do senso comum de analisar o trabalho mediado por plataformas como resultado exclusivo da condição individualizada concreta do trabalhador bem perfilada na aparência de autonomia e liberdade, que muitas vezes é total ou exclusivamente singular. Focou-se sim na totalidade sobre a coletividade dos trabalhadores - frequentemente referida como "multidão" pelo seu perfil amorfo, para fins de análise dos expedientes de controle sobre o trabalho alheio.

Por isso, a análise deu-se pelo viés da totalidade da relação, no sentido de olhar para a "empresa" que estrutura a atividade e 
Plataformas digitais e regulação trabalhista: precificação e controle do trabalhador neste novo... Murilo Carvalho Sampaio Oliveira

não olhar para um trabalhador individualizado, às vezes, perdido numa "trama" alheia. Justamente no processo de totalização e de compreensão das relações sociais constitutivas da noção, demarcadamente histórica, de tecnologia, percebe-se a desproteção nesse modo de trabalho provém mais da força ideológica e da correlação das disputas políticas-econômicas do que de argumentos tecnológicos, seja nas versões de um determinismo ou solucionismo tecnológico.

O ponto de partida foi a reflexão sobre a tecnologia e sua imbricação com os processos produtivos, em especial a concepção da natureza cultural e histórica de tecnologia como forma de trabalho abstrato e as questões contemporâneas dos algoritmos e produção massiva de dados (big data). Adiante, foram investigados os caracteres e tipologias das plataformas digitais de trabalho como o novo modelo tecnológico de organização do trabalho em ascensão, ressaltando o contraste entre a eficiência econômica desta atividade e a precariedade das condições concretas de trabalho daqueles sujeitos classificados como parceiros e autônomos. Em seguida, demonstrou-se a aplicabilidade da regulação do Direito do Trabalho para aquelas plataformas digitais classificadas como dirigentes, especificamente pela retomada do critério da dependência econômica mediante o método da precificação. Durante todo o texto, os exemplos dados estão ancorados a partir da empresa Uber, como ilustração da análise deste caso concreto e não em abstrações sobre os modos e condições de trabalho em plataformas.

\section{Trabalho e Tecnologia}

A pandemia do Covid-19 acelera de sobremodo o anterior trajeto expansionista da tecnologia digital. As mais variadas ações humanas no ambiente não-presencial propiciam a construção simbólica e ideológica da noção de "mundo digital" que organiza uma tipologia de economia - e, igualmente, um modo de trabalho 
Plataformas digitais e regulação trabalhista: precificação e controle do trabalhador neste novo... Murilo Carvalho Sampaio Oliveira

- apropriada a este ambiente virtual. Impõe-se, assim, perquirir as imbricações entre trabalho, tecnologia (digital) e sociabilidade.

A informação é elemento central desta contemporânea construção tecnológica, viabilizando até a ideia de que a ação sobre conhecimento produz mais conhecimentos, o que Castells (2011) designa por "informacionismo" e os ciclos de realimentação entre inovação e informação. Neste paradigma informacional, as tecnologias são baseadas em agir sobre a informação e na penetrabilidade na vida cotidiana, o que estimula modelos empresariais baseados em uma rede ou conglomerado de grandes empresas e pequenas e médias, sob direção de um projeto comum.

Castells (2011, p. 267) descreve a ideia geral do pós-industrialismo como a compreensão de que a geração de conhecimento seria o principal vetor da atividade econômica na sociedade da informação. O eixo predominante da economia seria, então, a prestação de serviços em razão do declínio da atividade industrial, com a consequente valorização das profissões especializadas em conhecimento. Esta organização empresarial em rede permite a precariedade do trabalho por meio de terceirização e a subcontratação, embora o autor ressalte que a imbricação entre inovação tecnológica e desvalorização do emprego seja uma expressão mais de ordem política e econômica, conforme os fatores de cada país, do que um dado técnico.

Em Deleuze (1990), é possível antecipar que a atividade econômica se organiza de modo disperso e desterritorizalizado no sentido de mecanismos de controle distintos daquele típico controle fabril fordista. O "controle ao ar livre" exposto por Deleuze é de índole subjetiva e associado às estratégicas comunicativas de liberdade, bem adequado às dinâmicas de atividades de serviços. Han (2020) prossegue caracterizando a sociedade atual como igualmente diversa daquela sociedade disciplinar foucaultiana - a fábrica era um exemplo sintomático daquele modelo -, apontando que o controle por desempenho que, na dimensão da subjetividade, resulta maior produtividade num cenário de aparência de 
Plataformas digitais e regulação trabalhista: precificação e controle do trabalhador neste novo... Murilo Carvalho Sampaio Oliveira

autonomia, o que denomina de coincidência entre liberdade e coação que gera uma "auto-exploração".

Nesse contexto de pós-industrialismo, informacionismo, economia de serviços e organizações desterritorializadas, as atuais e profundas mudanças tecnológicas recebem o epíteto de Quarta Revolução Industrial por Schwab (2016), que distingue tais novidades daquelas relacionadas à microeletrônica, semicondutores, computação pessoal e internet. A inteligência artificial, robótica, internet das coisas, veículos autônomos, impressão em terceira dimensão, nanotecnologia, biotecnologia, ciências dos materiais, armazenamento de energia e computação quântica são apresentados como artefatos da revolução tecnológica em curso. As atuais transformações tecnológicas se dão em alta velocidade exponencial e com tamanha amplitude e profundidade que as mudanças são sistêmicas diante de cada vez mais interações entre os sistemas físicos e virtuais.

Quando essa concorrência se torna mundializada, essa tecnologia é também estruturada como meio principal de organização das empresas. Com isso, Wolff (2009) afirma que a concorrência da globalização funciona como fator de expansão das tecnologias de informação e comunicação. Com as tecnologias de informação e comunicação (TIC), a gestão da informação então é a estrutura organizativa que, no modelo digital de empresa, governa com mais controle e onipresença os fatos e as ações dos envolvidos, mediante os registros desses como dados, viabilizando cada vez mais programações, aqui como sinonímia de algoritmo.

Um dos conceitos chaves deste novo padrão tecnológico é o algoritmo. Mazzotti (2017) conceitua algoritmo digital como conjunto de instruções, formuladas em linguagem de computador, para a resolução de problemas, em que uma entrada correta e a observância das instruções irá resultar na saída desejada. Ao empregar esta noção de algoritmo ao modelo digital, acrescenta que os algoritmos digitais aspiram a mecanização do pensamento humano com o propósito de torná-los mais eficientes e confiáveis. Contudo os problemas da falta de conhecimento total do algo- 
Plataformas digitais e regulação trabalhista: precificação e controle do trabalhador neste novo... Murilo Carvalho Sampaio Oliveira

ritmo, sua base de dados de entrada e suas instruções geram as questões de opacidade, tornando pouco transparentes tais programações.

Para os usuários de sistemas do ciberespaço, os algoritmos, conforme denuncia Silva (2017, p. 323), tem um alto potencial de condicionamento de condutas sobre seus usuários. Por não terem conhecimento, controle ou mesmo a capacidade de modificação sobre as regras de funcionamento dos algoritmos, os usuários figuram numa posição de dependência virtual ou tecnológica em relação àquele que detém ao código-fonte. Por outro lado, este mesmo código-fonte implementa uma governamentalidade algorítmica que, segundo Rouvroy e Berns (2018), que se dá em três momentos: coleta de quantidade massiva de dados; tratamento de dados e produção de conhecimento; ação sobre comportamentos. Estas noções de tecnologia digital e algoritmo são essenciais para a compreensão do conceito de plataforma digital de trabalho.

\section{Plataformas Digitais de Trabalho}

As aplicações tecnológicas citadas acima constituem o novo modelo de negócios designadas como plataformas digitais de trabalho que, junto com o comércio digital e "plataformas industrias" (indústria 4.0), formam o cenário mais macro da economia digital, ora também chamada de capitalismo de plataformas, economia de bicos (gig economy) ou economia do compartilhamento (sharing econmoy). Em Caldas (2020), percebe-se como as empresas formatadas em plataformas com interesse lucrativo não se enquadram, em termos reais, como economia do compartilhamento. Kalil (2020) a presenta extensa revisão bibliográfica sobre as diversas perspectivas teóricas que conformam a ideia de capitalismo de plataforma, precisamente para enfatizar a desigualdades destas trocas e a precariedade do trabalho.

Estruturadas em alta capacidade de processamento, com mineração e tratamento de quantidades imensas de dados por 
Plataformas digitais e regulação trabalhista: precificação e controle do trabalhador neste novo... Murilo Carvalho Sampaio Oliveira

meio de algoritmos e trânsito na rede mundial de computadores, as plataformas digitais são, conforme Srnicek (2018), infraestruturas digitais que permitem a interação de mais de um grupo e assim se posicionam como intermediárias que conectam usuários diferentes como clientes, anunciantes provedores produtores e distribuidores. Mais do que apenas conectar os seus usuários, as plataformas transcendem esta faceta tecnológica e comunicativa, porque constroem um modo de interação capitalista de compra e venda de diversas mercadorias, no sentido de governar e delimitar as possibilidades de ação dos seus usuários.

O modelo das plataformas de trabalho e outros tipos é sobretudo um modelo baseado na análise, tratamento e atuação conforme os dados coletados. O registro massivo destes dados de trabalho e consumo, significa que a vivência humana (inclusive as atividades produtivas) é anotada na forma de dados. Como estes registros indicam probabilidades do comportamento e uma ampla representação de traços individuais, inclusive bem organizadas por agrupamentos de identidades e semelhanças ("bolhas").

Tais registros, na lógica capitalista, são geridos como mercadorias. Então, o trabalho plataformizado gera duplo valor: o próprio trabalho e os seus registros sobre conjunto de informações sobre sua execução. Srnicek (2018) denuncia que a atuação digital de consumidores e trabalhadores em plataformas é constitutiva de dados que são fonte de valor para aquele modelo de negócio. Trata-se de trabalho gratuito da multidão que produz riqueza, mas é apropriado apenas pelo organizador do ambiente de interação digital.

A fim de enfatizar o maior poder de controle e vigilância que o ambiente digital proporciona, Vallas e Schor (2020) falam nas plataformas como "gaiolas digitais", tendo em vista que o mapeamento permitido pelos dados viabiliza uma cartografia total da dinâmica empresarial de uma atividade. Especialmente viabiliza a identificação das relações entre demanda e sazonalidade, permitindo que a plataforma saiba os padrões de oferta e procura e a tipologia dos bens demandados. Com tais informações em tempo 
Plataformas digitais e regulação trabalhista: precificação e controle do trabalhador neste novo... Murilo Carvalho Sampaio Oliveira

real e localizadas geograficamente, é factível ao detentor das informações sobre demanda manipular a oferta, tanto em relação aos trabalhadores disponíveis como em relação as empresas fornecedoras dos bens ou serviços. As plataformas assim exercem uma governança (privada) e de certa forma oculta nos seus algoritmos sobre os seus parceiros e usuários.

Além dessa dimensão de dataficação, é imprescindível entender a plataformização do trabalho como um modelo de imbricação da financeirização da atividade econômica com a racionalidade neoliberal do sujeito como empreendedor de si, na linha sugerida por Grohmann (2020). A métrica de performance e resultado da gestão algorítmica - vide o exemplo da nota individual - funciona como mecanismo de autocobrança e internalização dos riscos do negócio como riscos apenas e exclusivamente individuais do trabalhador. $O$ autor esclarece que o termo plataformização do trabalho é mais apropriado do que uberização, exatamente porque consegue captar a variedade dos modos de trabalho mediado por plataformas e a situação de maior dependência do trabalhador para com estes ambientes.

Nas plataformas digitais de trabalho, a precariedade social do trabalho contrasta com a ideia de evolução tecnológica ao atribuir uma série de invisibilidades de natureza técnica-ideológica aos trabalhadores. Cherry (2017) denomina de trabalho invisível virtual, exemplificando-as como aquelas tarefas manuais de assistir vídeos e classificá-los em próprios ou impróprios para sua publicação em redes sociais, no sentido de que esses trabalhos não são reconhecidos ou vistos pelo público externo a organização da rede social. Isto é, vende-se trabalho humano real como simulacro de inteligência artificial, na conformação antiga de tratar trabalhadores como mercadoria. Outra maneira de tornar invisível trabalho das pessoas no âmbito das plataformas, é considerá-los como outras designações diversas de trabalhadores e empregados como tarefeiros ("taskers"), turcos ("turkers"), entre outros, negando-lhes a condição de sujeitos de direitos ou o reconhecimento público 
Plataformas digitais e regulação trabalhista: precificação e controle do trabalhador neste novo... Murilo Carvalho Sampaio Oliveira

de que estes desenvolvem uma atividade laboral no âmbito desta plataforma.

A imposição da qualificação de "parceiro" ou trabalhador autônomo ("independent contractor") pela empresa estruturada em plataforma resulta, prima facie, na exclusão da aplicação da proteção social e trabalhista, isto é, uma desconexão deste modelo de negócios com o Direito do Trabalho (2019). Com isso, há a eliminação das três seguranças básicas do Direito do Trabalho segundo Supiot (2016): segurança física concernente às condições de ambientes trabalho que não Ihe provoquem ofensa física ou lhe ofendam a dignidade e psique; segurança biológica com a limitação da jornada; e a segurança econômica como o salário mínimo. Além disso, há apenas remuneração pelo tempo de trabalho efetivo de trabalho, com o desprezo dos tempos de disponibilidade ao trabalho e até, em algumas plataformas, ocorre a desconsideração do tempo de deslocamento até o local de início da demanda e seu retorno. Isto legitima a noção de trabalhador por momento e conforme a demanda ("just in time") e, naturalmente, sem qualquer proteção social, como sinalizado por Abílio (2014).

Outro componente da precariedade é a transferência de despesas e riscos da atividade econômica para o trabalhador. Ao transferir as despesas de aquisição e manutenção dos instrumentos de trabalho e igualmente das despesas dos riscos da atividade (acidentes, multas, ociosidade, etc), obtém-se mais eficiência econômica com a delegação dessas despesas ao trabalhador. Antunes (2018) descreve o modelo da Uber como exemplo da precariedade estrutural, uma vez que transfere riscos e despesas para o trabalhador, embora estabeleça uma relação de assalariamento, todavia, sem o cumprimento dos deveres da legislação trabalhista, além tomar intermitência da ocupação o padrão para os trabalhadores.

Para Srnicek (2018), a Uber e seu modelo enxuto se organiza pela externalização de propriedades essenciais ao negócio (veículos e celulares), custos do trabalho (ao classificar seus condutores como autônomos) e os riscos do negócio (acidentes, multas, entre outros), denominando-a de plataforma "austera". Disto, constata- 
Plataformas digitais e regulação trabalhista: precificação e controle do trabalhador neste novo... Murilo Carvalho Sampaio Oliveira

-se uma clara coligação entre o modelo neoliberal da austeridade na organização econômica com a precariedade do trabalho das plataformas. Nisto, o autor circunscreve temporalmente a ascensão desse modelo de hiper-externalização e sua consequente precariedade ao período pós-crise econômico de 2008.

Filgueiras e Cavalcante (2020) desnudam que, ao contrário do discurso de novidade, o trabalho via plataformas é a antiga gestão de trabalho assalariado, mas com propagandas de negação desse assalariamento. Ao transferir as despesas de aquisição e manutenção dos instrumentos de trabalho e igualmente das despesas dos riscos da atividade (acidentes, multas, ociosidade, etc), a obtém-se mais eficiência econômica com a delegação dessas despesas ao trabalhador. A invisibilidade comunicativa e ideológica da condição de trabalhador assalariado funciona como expediente de transferência de despesas e assim mais proveito econômico sobre o trabalho alheio, além da subtração das despesas com o custeio dos direitos trabalhistas

\section{Regulação do Trabalho Digital}

A discussão sobre a regulação do trabalho mediado por plataformas digitais se impõe em razão da miríade de conflito entre estas e seus trabalhadores. A forma jurídica desta relação tem sido instrumentalizada por documentos unilaterais (termos de uso) que, materialmente, são um contrato de adesão. Daí surge uma série de tensões, tanto na dimensão de direitos fundamentais como na falta de informação e contraditório nas exclusões ou em outras punições aplicadas pelas plataformas aos trabalhadores, como na dimensão cível na falta de boa-fé objetiva ou pela necessidade de reparar prejuízos e despesas realizadas em proveito da plataforma ou ainda na dimensão trabalhista com o debate sobre o vínculo e a incidência dos direitos laborais. Como não há regulação pública, perdura, até então, o autogoverno das plataformas sobre estas relações, bem construído em termos ideológicos e privatistas como 
Plataformas digitais e regulação trabalhista: precificação e controle do trabalhador neste novo... Murilo Carvalho Sampaio Oliveira

"autogovernança". Entretanto, algumas decisões judiciais cíveis ou trabalhistas quebram esta regência unilateral da relação para impor deveres previstos na lei cível ou na legislação trabalhista via reconhecimento da relação de trabalho dependente.

Para se cogitar a normatização de práticas sociais, o primeiro passo é o diagnóstico o mais pormenorizado possível do fenômeno com o esforço para buscar denominações e classificações de acordo com suas características. As questões de denominação, numa perspectiva crítica, devem buscar retratar no título um resumo fiel do fenômeno que representam. Quando um tema é incipiente, os debates de nomenclatura são importantes para evitar compreensões superficiais ou equivocadas e para desvelar as naturalizações que o senso comum produz sobre a realidade cotidiana.

A primeira e a mais mencionada é a designação como "uberização", numa forte metonímia na qual um tipo específico de plataforma de transporte individual em veículo privado, graças à intensa ação comunicativa e expansão econômica, funciona como epíteto para o modelo geral de plataformas digitais de trabalho. Além desse sentido de modelo econômico austero, Abílio (2017) demonstra outra semântica de uberização que expressa a noção de trabalho precário e de modelo exploratório em relação aos seus trabalhadores, que, no caso brasileiro, representa uma continuidade com outras precariedades laborais daqueles que sempre vivenciam a "viração" de ocupações informais ou desprotegidas.

Apesar frequência e prevalência do uso da expressão "uberização" tanto no sentido de modelo econômico como de gestão do trabalho pela precariedade, o modelo da empresa Uber destoa sensivelmente de outras plataformas, o que prejudica sensivelmente sua utilização, na especialmente na perspectiva crítica. Portanto, emprega-se o termo "plataforma digital de trabalho", epíteto que indica uma infraestrutura não presencial que promove (e às vezes dirige e controla) a interação entre grupos de trabalhadores e de contratantes destes. Esta delimitação semântica de plataforma como local de encontro advém de Srnicek (2018) e Carelli, Oliveira e Grilo (2020). Essa noção também é encontrada na definição pro- 
Plataformas digitais e regulação trabalhista: precificação e controle do trabalhador neste novo... Murilo Carvalho Sampaio Oliveira

posta pela Reforma Tributária (2020), a qual enfatiza a função de intermediação não-presencial e meios eletrônicos como elementos distintivos do modelo de negócios, no intuito de distingui-lo dos demais para fins de tributação.

Na pesquisa sobre plataformas que mediam e/ou gerenciam atividades laborais, outrora designadas como "virtuais" ou "eletrônicas", utilizada na legislação portuguesa de 2018 (PORTUGAL: 2018), a expressão "plataforma digital" foi acolhida como adequada, porque a semântica de virtual - aquilo não presencial ou não real - não contempla a dimensão de trabalho executado presencialmente (offline) de diversas plataformas, como uma viagem em veículo privado, a entrega de uma comida ou o trabalho doméstico.

A noção de "eletrônica" realça a perspectiva física - isto é, de equipamento físico ("hardware" na linguagem informática), quando a ideia de "digital" referida como uma ambivalência entre uma linguagem comum das máquinas informáticas e homens que é, contraditoriamente, produzida por "digitais" humanas, sendo concomitantemente ação humana real que produz dados virtuais. A expressão "on line", além dos problemas de todo anglicismo, não comporta as atividades que, ainda que demandadas via rede mundial de computadores, são executadas no mundo físico e presencial. Por isso, afigura-se mais adequada a denominação como plataformas digitais de trabalho, porque exprime a dualidade de um fenômeno que se organiza e se gerencia no ambiente virtual, mas se concretiza e afeta os sujeitos envolvidos na realidade.

Ainda nas questões vocabulares, é estratégico recusar a designação de trabalho em "aplicativos". Diante de organizações com objetivos econômicos subjugados pela produção de lucro, é preciso antes tratar estas plataformas como empreendimentos que se estruturam numa gestão digital com a utilização de um sítio eletrônico (site), algoritmos, banco de dados massivos (big data) e programas de computação, nos quais alguns - mas não todos - funcionam em formato reduzido para sua viabilidade em celulares, o que se chama de aplicativos. Se aplicativo é uma porta (pequena) de acesso àquele empreendimento digital, igualmen- 
Plataformas digitais e regulação trabalhista: precificação e controle do trabalhador neste novo... Murilo Carvalho Sampaio Oliveira

te acessível pelo site, não é este nome o constitutivo deste novo modelo empresarial, até porque em plataformas de microtarefas, como a Getninjas, não há aplicativo. Mesmo sendo o mais frequente e até mais sonoro e referido nome, insistir na nomeação de aplicativos como sinônimos de empresas estruturadas no modelo de plataformas é expandir a superficialidade do senso comum e simultaneamente ocultar a dimensão econômica e lucrativa das atividades de humanos que a organizam em redes tecnológicas.

Definida a nomenclatura, cabe mencionar, dentre tantas, duas tipologias que explicam de modo pertinente a atuação das plataformas de trabalho.

A classificação mais conhecida sobre as plataformas é aquela proposta por De Stefano (2016), o qual se refere às plataformas online como denominação para as empresas que organizam ou fazem intermediação entre trabalhadores e contratantes. Dividindose estas em dois grandes tipos, o autor apresenta o primeiro chamado de "trabalho em multidão" ("crowdwork"), o qual é bastante variado indo de projetos, tarefas ou até microtarefas, embora todas caracterizadas por serem executadas via rede mundial de computadores (internet). O segundo grupo engloba atividades também variadas (transportes, entregas, limpeza, serviços administrativos e jurídicos), que são prestadas presencialmente mediante demanda por meio de aplicativos, o que esclarece o nome de trabalho sob demanda ("work-on-demand via apps"). A partir disso, o próprio trabalho de multidão é constituído no meio digital e assim bastante desvinculado dos aspectos territoriais, enquanto que o trabalho sob demanda é acionado e encerrado no ambiente virtual, mas prestado na dimensão física presencial.

Carelli, Oliveira e Grillo (2020) dividem estas empresas em dois agrupamentos. Primeiro, plataformas puras que apenas mediam a relação entre os consumidores e os tomadores do serviço, sem qualquer controle e ingerência sobre o trabalho. Segundo, plataformas híbridas que, além da função estrita de aproximação de pessoas, exercem controle e direção sobre os trabalhadores. Assim, as plataformas híbridas são controladoras e dirigentes no 
Plataformas digitais e regulação trabalhista: precificação e controle do trabalhador neste novo... Murilo Carvalho Sampaio Oliveira

sentido de que ordenam e governam os serviços que oferecidos entre os diversos grupos.

Reconhecidas as imprecisões e superficialidades vocabulares e diante de classificações lastreadas na atividade desenvolvida, a regulação das plataformas digitais de trabalho deve guiar-se sobre a dimensão real de suas atividades, ou seja, é preciso dar assertividade ao princípio da primazia da realidade. As invisibilidades, agora adstritas ao plano jurídico, são artificialmente criadas pelas plataformas. Nos termos de uso da Uber (2020), a linguagem da "autogovernança" transmuta discursivamente a plataforma em canal de comunicação ou lugar de venda de serviços ("marketplace"), trabalhador em "usuário" e/ou "cliente", punição em "desativação", controle de desempenho em "nota mínima", vigilância constante via geolocalização, inclusive com gravação de áudio, em "monitoramento" e salário em "preço por viagem". Deste modo, uma investigação crítica confere maior importância à realidade dos fatos e não aos nomes artificial e unilateralmente estabelecidos, a fim não se legitimar a conhecida "manipulação abusiva da qualificação do contrato" dirigida a elidir a proteção trabalhista, como apontam Amado e Santos (2017).

Nas plataformas que se perfilam apenas como mercado de trabalho ("marketplace"), o vendedor de "trabalho", formalmente classificado como livre e autônomo, deve agir como um trabalhador livre numa economia de mercado. Somente a este livre trabalhador cabe a negociação e a barganha da sua mercadoria: o trabalho. Expedientes de controle, seja de índole econômica, de desempenho ou fiscalizatória, corroem essa ideia de autonomia e impedem que, nestas circunstâncias, a plataforma seja apenas uma mediadora ou conectora. Como ilustração, uma rádio taxi que tão somente se atenha a promover a comunicação entre clientes e taxistas seria assim uma mediadora legítima e não lhe cabendo a imputação de empregadora.

No plano oposto, há relação de emprego quando a plataforma não se adstringe à função tradicional de plataforma de mera conexão. No empenho da crítica, é imperativo ressalvar que nomear 
Plataformas digitais e regulação trabalhista: precificação e controle do trabalhador neste novo... Murilo Carvalho Sampaio Oliveira

como plataforma digital àquelas que são controladoras oculta, em parte, que estas empresas são mais do que meras conectoras, porque ao organizar, controlar e se apropriar de uma atividade elas funcionam mais como empresas de transporte ou entrega sob a estrutura de plataforma digital. Por esta razão, é até mais adequado chamar certas plataformas dirigentes de empresas de transporte, tendo em vista que é esta sua atividade principal sob o prisma econômico.

Aliás, o conceito de empresa, inclusive aquele constante da CLT, é suficientemente amplo a comportar este modelo econômico. Quando as plataformas assalariam e dirigem o trabalho alheio, elas se amoldam ao conceito de empregador da CLT (art. $2^{\circ}$ ) e haverá, então, a necessidade da regulação por meio do vínculo de emprego se, além da dependência, estiverem presentes os demais requisitos do art. $3^{\circ}$, notadamente diante de episódicas e singulares dificuldades de caracterização elemento da não-eventualidade.

Por outro lado, a negativa da ocorrência de controle e apropriação neste modelo empresarial é referenciada, principalmente, na posição individualizada do trabalhador que teria liberdade de ativação e desativação e, consequentemente, seria autônomo. Contudo, Leal e Oliveira (2021) argumentam que a liberdade logo se mostra mitigada por razões de ordem tecnológica e econômica: o autogoverno do condutor da Uber pressupõe o conhecimento do código-fonte daquela infraestrutura digital, a negociação sobre os critérios de programação dos algoritmos e a fixação do valor da venda de força de trabalho.

Quando enfocada a dimensão coletiva deste modelo econômico, é muito mais perceptível a direção exercida por certas plataformas. No caso da Uber, Castro (2020, p. 204) demonstra quando se observa a multidão de trabalhadores e as fórmulas algorítmicas que os conduzem a se ativar, a prosseguir nas extensas jornadas ou mesmo a mudar de áreas guiados pela tarifa dinâmica e a repetição de um padrão de trabalho pré-definido para se manter com uma nota mínima, há clareza na constatação de forte direção dos serviços por mecanismos indiretos e invisíveis. 
Plataformas digitais e regulação trabalhista: precificação e controle do trabalhador neste novo... Murilo Carvalho Sampaio Oliveira

Assim, a regulação trabalhista mostra-se pertinente às plataformas dirigentes, justamente porque os expedientes de controle e apropriação utilizados desqualificam estas empresas como apenas intermediárias. Entretanto, entende-se que o elemento de controle primordial e estrutural deste modelo não é a heterodireção, mas a precificação.

\section{Controle por Precificação: A Velha Dependência Econômica}

Como visto anteriormente, quando a plataforma digital adota mecanismos de controle e direção sobre o trabalho alheio oferecido aos tomadores-demandantes, esta empresa abandona, por sua própria escolha, o papel de mediador e assume, na realidade fática, a condição de empresa que assalaria trabalhadores. Dos diversos métodos de controle utilizados, a precificação - que é bastante comum em plataformas digitais de trabalho por demanda ou de microtarefas - denuncia como o dirigismo econômico é um artifício, atualmente de feição tecnológica, de domínio sobre os trabalhadores.

Atribuir o preço do labor alheio é um antigo método de gestão no modelo capitalista. No século XIX ou mesmo antes, encontram-se diversas narrativas sobre o sistema fabril externalizado de "salário por peça", como se constata nas descrições de "putting-out-system", bem adequadas ao capitalismo mercantil da época e sua intensa circulação de bens. Logo, a fabricação dos produtos poderia ficar a cargo de parceiros econômicos ou mesmo assalariados, desde que estivessem sob um controle geral à distância. Naquela fórmula de controle não presencial, a gerência do trabalho assalariado se valia do pagamento atrelado ao resultado efetivo do trabalho, conseguindo assim impor maiores tempos de trabalho e também transferir alguns custos e riscos da atividade ao trabalhador. 
Plataformas digitais e regulação trabalhista: precificação e controle do trabalhador neste novo... Murilo Carvalho Sampaio Oliveira

A par dos seus estudos em economia política, Marx (2009; p. 525) descreve esse modelo de trabalho em domicílio como uma seção externa da fábrica, ou seja, a produção em domicílio é o primeiro expediente capitalista de externalização da produção. Como os custos de produção no trabalho em domicílio são do próprio trabalhador, há uma tendência de economia dos meios produtivos que implica maior sacrifício para a força de trabalho.

O arcabouço socioeconômico diferencia o assalariamento por peça de uma simples compra de produtos no mercado. No sistema de salário por peça, o contratante define previamente os caracteres do bem a ser produzido e frequentemente é o principal comprador destes, ou seja, o controle se manifesta previamente à venda quando o comprador habitual define o bem e sua qualidade. Já o trabalhador não produz mercadorias para o livre mercado, mas ao contrário atende ao chamado para produzir algo específico para um contratante. Com isso, o que se compra no sistema do salário por peça não é a peça em si, que só pode ser vendida para o demandante e por aquele é precificada, mas força de trabalho numa "forma metamorfoseada" (COLLI, 2008, p. 76).

Quando a qualidade e outros aspectos do produto estão previamente definidos, a supervisão da execução do trabalho de produção - então realizada presencialmente e com fiscalização hierárquica - perde relevo, tornando desnecessária a "inspeção do trabalho" (MARX, 2009, p. 640). A apropriação se estabelece então pela precificação prévia e não mediante uma intensa heterodireção, bem própria do modelo de gestão fordista que seria hegemônico no século seguinte.

Tomando por exemplo a fase juvenil da Indústria (1797-1815), Marx (2009, p. 643) avalia que o salário por peça é a forma mais adequada ao modo capitalista de produção, pois simultaneamente estimula a prolongação da jornada de trabalho e também acarreta rebaixamento do salário. Ao vincular maior remuneração à produtividade, o modelo do salário por peça entroniza no trabalhador o desejo por intensidade e maior extensão do tempo de trabalho (GUANAIS, 2018). Uma fórmula ardil de sugerir uma "porcentagem" 
Plataformas digitais e regulação trabalhista: precificação e controle do trabalhador neste novo... Murilo Carvalho Sampaio Oliveira

nos ganhos, mas que, por ser bastante diminuta, não foge à forma social de assalariamento, inclusive com a recorrente participação de intermediários (MARX, 2009, p. 640).

Com o estímulo econômico advindo de receber mais se gerar maior produção, o trabalhador se engaja com entusiasmo neste modelo de gestão, não percebendo que a prolongação da jornada com a continuidade do valor da peça já representa por si só uma baixa no preço do trabalho (MARX, 2009, p. 641). Isto porque no sistema de salário por peça o valor atribuído ao produto não é definido apenas com o valor criado de cada peça produzida, mas sim também é estabelecido a partir de tempos médios da produção, de sorte que esse pagamento por peça/produto é fixado indiretamente pelo tempo de produção.

A explicação desse entusiasmo do trabalhador pelo modelo de salário por peça é justamente essa combinação de promessas de liberdade sobre o tempo de trabalho e obtenção de riqueza resultante da somatória da sua produtividade individual. De modo implícito, esse modelo promete a máxima liberal de que o trabalho livre produz propriedade, no sentido de que a riqueza criada pelo trabalho é propriedade natural, como diria Locke (1978), daquele que produziu a ação, forjando uma falsa ideia de "comerciante de si" (COLLI, 2008, p. 83-84). Entretanto, como os ganhos são limitados previamente pelo controle econômico, a concretude desse trabalho se desnuda como assalariamento disfarçado, com igual ou superior apropriação do trabalho alheio por quem estabeleceu a dinâmica da relação.

Na contemporaneidade, Wolff (2020, p. 97) e Colli (2008, p. 75) opinam que as novas tecnologias de informação e comunicação viabilizam um novo feitio aos antigos "putting-out-system" e "facção", respectivamente. Se atualmente a circulação de bens e serviços assume, segundo Lazzarato (2019, p. 12), a centralidade na economia política, lugar ocupado pela produção material fabril, o regresso das estratégias do capitalismo comercial de controle via mecanismos econômicos do poder de precificar bens e trabalho igualmente é retomado. 
Plataformas digitais e regulação trabalhista: precificação e controle do trabalhador neste novo... Murilo Carvalho Sampaio Oliveira

Externalizar ou delegar atividades é, desde o pós-fordismo, uma estratégia recorrente de acumulação flexível do capitalismo que não mais despende capital fixo em unidades fabris, insumos, despesas de manutenção e até certos custos da legislação trabaIhista. Contudo, esse movimento de "pôr para fora" (outsourcing) a territorialidade da produção de bens materiais não significa transferência ou perda dos mecanismos de controle geral sobre esta atividade econômica.

Mesmo antes da ascensão das plataformas, havia uma dualidade entre visibilidade da marca e invisibilidade de seus trabalhadores. Abílio (2014) recoloca que enquanto o trabalho se invisibiliza pelas práticas de externalização, a marca empresarial ganhava demasiada visibilidade. A expansão e valorização da marca nas empresas representaria, segunda a autora, ainda mais consolidação do processo de fetichização. São três movimentos deste fetiche: o trabalho que produz os bens desta marca vale cada vez menos; a marca, bem imaterial ou mera informação aparece como algo autônomo e, terceiro, constrói-se a ideia de que a marca agrega o valor ao bem, inclusive a justificar preços maiores em razão daquele signo.

Nas atuais cadeias globais de produção, devidamente modularizadas, as empresas centrais se encarregam de definir a atividade e/o produto e controlar a circulação, valendo-se de subcontratações e terceirizações sem, todavia, perder o comando geral da cadeia. Em certa medida, as plataformas que vendem serviços presenciais reproduzem esse modelo de máxima externalização ao definir uma atividade - muito propriamente a partir da construção de uma marca com suas estratégicas comunicativas (marketing) -, ao criar uma gestão por algoritmos que precifica o trabalho alheio e ao transferir custos de aquisição e manutenção de instrumentos de trabalho para seus trabalhadores "parceiros". Fontes (2017) designa isto como a ação de "formas mais concentradas da propriedade, que viabilizam o controle econômico do processo na parte que lhes interessa, o controle da extração, a captura do mais-valor e sua circulação de volta à propriedade". 
Plataformas digitais e regulação trabalhista: precificação e controle do trabalhador neste novo... Murilo Carvalho Sampaio Oliveira

Por exemplo, Dubal (2020) sustenta que as plataformas adotam o modelo do salário por peça no padrão digital ("digital piecework"), com o mesmo discurso de liberdade e meio de obtenção de renda complementar do antigo trabalho domiciliar de facção do século XIX. Castro (2020) afirma que a Uber adota o modelo de salário por peça, precisamente por "unidade de obra" e que a externalização dos ativos (ou instrumentos) de trabalho é mais um expediente de redução de custos e precarização, porque fomenta uma confusão conceitual entre instrumento de trabalho e meio de produção, além de implicar redução de despesas com capital fixo e atribuí-las formalmente aos trabalhadores.

A centralidade da propaganda de diversas plataformas é justamente aquela "liberdade de trabalho", cujo real alcance é restrito à autogestão do tempo de trabalho, entretanto a precificação com sua tendência econômica de redução de valores funciona como método de forçar mais jornadas e redução de valores com o passar do tempo, o que se confirma nas diversas pesquisas sobre motoristas ou entregadores.

Por outro lado, relatos sobre a história da empresa da Uber indicam que a precificação variável dos valores das corridas eram um importante instrumento da gestão de trabalho. Conforme se inferiu de alguns testes feitos em Nova York, a fórmula tarifária de aumentar o valor corrida para o motorista com a permanência desta tarifa para o consumidor garantia que mais motoristas continuassem mais tempo trabalhando. Daí que Stone (2017, p. 174) conclui que a tarifa dinâmica da Uber foi um ajuste no modelo de gestão das viagens para dar suporte a demanda, inclusive podendo essa variação de tarifa ser feita manualmente.

A adesão dos trabalhadores às jornadas maiores nessas plataformas, tal como no antigo salário por peça, justifica-se no cálculo individual da vantagem prometida: mais viagens, mais remuneração. Todavia, não são usualmente computadas nesse cálculo de ganhos as diversas despesas efetuadas em razão do trabalho, a depreciação dos instrumentos de trabalho e uma série de riscos da atividade que podem acarretar prejuízos consideráveis. Isto 
Plataformas digitais e regulação trabalhista: precificação e controle do trabalhador neste novo... Murilo Carvalho Sampaio Oliveira

significa que, numa avaliação profunda e crítica, a promessa de maior remuneração é uma falácia e uma armadilha de engajamento do trabalhador e de individualização dos riscos da empresa, que muitas vezes manipula informações e não repassa integralmente as porcentagens que prometeu.

Mais uma nota é importante sobre estas transferências de despesas com aquisição e operação dos instrumentos de trabalho. Algumas plataformas apresentam a estratégia de controle decorrente do modelo do salário por peça: o controle pela dívida. Como se tratam de assalariados e assim não detentores de propriedades ou meios de produção, estas plataformas avalizam direta ou indiretamente o financiamento de veículos, mochilas, telefones e outros equipamentos para o trabalho. Lazzarato (2013) desvela como o uso neoliberal da dívida implica poder e assimetria com efeitos econômicos e subjetivos sobre o endividado. Logo, quando as plataformas promovem financiamentos para seus trabalhadores estão a realizar dois fortes controles econômicos: assalariamento e endividamento!

Retomando ao campo jurídico, justamente por sua externalidade à fábrica, as regras trabalhistas de limitação de jornada do século XIX não se aplicavam no trabalho em domicílio, além de que o conjunto de despesas para execução do trabalho eram por conta do trabalhador. Essa dificuldade do direito laboral, além dos problemas sociológicos e políticos que afetam os debates sobre a efetividade da proteção social do trabalhador no capitalismo, demonstra que as principais instituições e categorias chaves trabalhistas são feitas numa construção territorial e presencial, com forte influência da gestão fordista. Quando se trata de modelos externalizados e não-presenciais, o Direito do Trabalho, à semeIhança das dificuldades políticas - e não técnicas ou tecnológicas - para limitar a jornada do trabalhador externo, reencontra dificuldades para regular o trabalho totalmente em meio digital desde do teletrabalho às microtarefas via plataformas, bem como depara-se com a dificuldade de tentar encaixar uma subordinação "presencial" nos trabalhos sob demanda por plataformas. 
Plataformas digitais e regulação trabalhista: precificação e controle do trabalhador neste novo... Murilo Carvalho Sampaio Oliveira

Adiante, a concretude deste formato de gestão do trabalho desfaz a propalada liberdade. Como o trabalhador assalariado por peça não tem acesso livre ao mercado de trabalho, em razão de produzir um bem previamente demandado e padronizado pelo contratante, a legítima noção de liberdade de atividade econômica ali não se manifesta. Isso também ocorre em muitas plataformas digitais de trabalho que, além da função de mediação, definem previamente o padrão geral de trabalho e se valem de métodos opacos de direção, fiscalização e punição. Deste modo, a plataforma digital dirigente organiza o mercado e se impõe como elo de acesso do trabalhador aos clientes, o que se configura como uma dependência do trabalhador para com a plataforma porque sem esta não há como se vender aquele trabalho.

Essa "reinvenção do salário por peça" associada ao discurso de liberdade individual, inclusive anterior ao debate das plataformas digitais (COLLI, 2018), resgata uma construção de subjetividade do trabalhador assalariado como comerciante ou "empreendedor de si" que circula com sua mercadoria que é basicamente sua força de trabalho. Há uma construção ideológica para conduzir o assalariado a se reconhecer como capital e não como trabalho, o que explica de alguma forma o epíteto de "capital humano".

Em Dardot e Laval (2016), descortina-se a compreensão do neoliberalismo como um modo individual de vida (governamentalidade) centrado na concorrência individualista e numa respectiva subjetividade de "empresa de si" (racionalidade), o que igualmente coopta a ideia de autonomia para transformá-la em uma coerção flexível. No lugar de uma hierarquia exteriorizada do período fordista, o neossujeito se perfaz a partir de uma subjetivação do desempenho individual como resultado apenas da sua ação individual, aí deliberadamente ocultando o papel dos mecanismos de controle daqueles que organizam e se apropriam do trabalho assalariado. Para a gestão moderna há uma clara construção aliciada de subjetividade na qual as esferas do controle de desempenho e avaliação transpõe a dimensão profissional e também alcança a dimensão pessoal. Somente uma subjetividade empresarial que 
Plataformas digitais e regulação trabalhista: precificação e controle do trabalhador neste novo... Murilo Carvalho Sampaio Oliveira

maximiza a produtividade e a competitividade elucida como o próprio trabalhador realiza a vigilância sobre si mesmo, além de até celebrar a quantificação da avaliação na "nota" que lhe é imposta nos sistemas de plataformas.

A consequência da lógica do trabalhador como empresa de si é exatamente a desnecessidade da incidência dos marcos jurídicos protetivos para a relação salarial. Se todo sujeito trabalhador é um empresário no sentido de ser o único responsável pelo êxito do negócio, não faz qualquer sentido se cogitar o contrato de trabalho, até porque toda a responsabilidade é individual. Em verdade, isto é a retomada, com contornos de controle psíquico e ideológico, da concepção do trabalhador como mera mercadoria que deve ser igualada àquelas outras mercadorias vendidas por empresários. Fora das artimanhas de entusiasmos e das promessas de liberdade, o método do salário por peça é a forma mais austera da venda de força de trabalho como mera mercadoria.

\section{Dependência Econômica}

Na percepção de que o traço constitutivo do assalariado é a venda apenas de força de trabalho, recorre-se a uma compreensão ressignificada de dependência econômica (OLIVEIRA, 2012) como critério mais adequado à identificação vínculo empregatício do que as dimensões de subordinação jurídica que, em geral, vinculam-se às consequências dessa venda como supervisão, fiscalização ou punição. Mais relevante do que o trabalhador estar submetido a uma forte heterodireção, é ter o resultado econômico do seu trabalho apropriado por outrem.

A proposta é fixar a plena sinonímia entre a noção sociológica de trabalhador assalariado e a ideia de "dependência" sem adjetivos no âmbito do Direito. Considera-se que o substrato material (e extrajurídico) da forma jurídica de trabalhar "sob dependência" é a qualificação do trabalhador como despossuído, coagido e expropriado e, portanto, vendedor apenas de força de trabalho, 
Plataformas digitais e regulação trabalhista: precificação e controle do trabalhador neste novo... Murilo Carvalho Sampaio Oliveira

no sentido do valor de uso e não do valor de troca (mercadoria). Convém explicitar este raciocínio:

O sentido da expressão "venda de força de trabalho" refere-se ao bem cuja utilidade econômica é restrita, por depender do seu acoplamento a um empreendimento, mais precisamente pela sua conjunção com a propriedade (meios de produção). Sendo o trabalho um dos elementos da empresa, seu destino é o de estar contido nesta. O trabalho dissociado da propriedade não pode agir como empresa; somente lhe cabe retornar a empresa pela "venda compulsória de força de trabalho" (OLIVEIRA, 2019, p. 218).

O entendimento de uma assimetria - inicialmente prévia à celebração e depois contínua à execução - do contrato de emprego, como resultante da forma de organização do trabalho na sociedade capitalista, é caracterizada no juslaboralismo como o fundamento da hipossuficiência que, por consequência, reclama um modelo protetivo para esta disciplina. Aliás, Grillo (2008, p. 130) cogita a proteção constitucional para todo o trabalhador em situação de dependência econômica, empregado ou não, como medida de justiça e correção do "um desequilíbrio estrutural entre os contratantes".

Adjetivar como "econômica" essa dependência tem dois objetivos relacionados aos fundamentos do trabalho assalariado e sua perspectiva dialética crítica. Primeiro, o fundamento para o trabalho juridicamente dependente reside no molde da relação econômica de assalariamento, explicitando que a fundamentação extrajurídica é indispensável para a apreensão mais totalizante dos fenômenos jurídicos, sobretudo diante das abordagens sociojurídicas críticas. Segundo, ressalta-se a natureza legitimadora do Direito do Trabalho em reproduzir, ainda que com alguma civilidade, a relação econômica de exploração do trabalho alheio, recolocando neste debate que o núcleo da relação de trabalho diz respeito à propriedade e ao poder que esta, no modelo capitalista, 
Plataformas digitais e regulação trabalhista: precificação e controle do trabalhador neste novo... Murilo Carvalho Sampaio Oliveira

exerce sobre os não-proprietários (assalariados). Falar em dependência econômica é explicitar a centralidade da propriedade na constituição das relações de trabalho:

A chave da compreensão crítica da dependência é, então, seu conteúdo econômico, como correlato à ausência de propriedade. Trata-se da percepção de que esta forma de trabalho dependente é estruturada pelas condições econômicas da sociedade capitalista. Em nome da propriedade, coage-se ao trabalho, como também, por força da propriedade, expropria-se a riqueza criada pelo trabalhador (OLIVEIRA, 2012, p. 221).

Se a propriedade é o elemento nuclear do molde econômico da relação, a discussão jurídica sobre a apropriação dos frutos do trabalho coaduna com a ideia ressignificada de dependência econômica. Nessa linha, a doutrina jurídica espanhola a partir de Olea (1969) desenvolveu bastante esse debate, assentando na concepção econômica da estrutura do trabalho assalariado, usando a categoria de alienação ou alheamento ("ajenidad" em espanhol), numa perspectiva mais ampla crítica do que o uso da subordinação jurídica. Há, então, critérios jurídicos fora do campo da subordinação que tentam se conectar com a leitura econômica.

No contexto tecnológico das plataformas, constata-se que, apesar dos anúncios de liberdade e autonomia, perduram ali relações assimétricas de trabalho e insertas no padrão de assalariamento numa feição moderna de salário por peça. Conforme De Stefano (2020) e Adam-Prassl (2020), a gestão por algoritmos e decisões baseadas em inteligência artificial, realçam o espectro de poder daquele que organiza a plataforma, especialmente pelo domínio das informações massivamente recolhidas (big data) e das escolhas de quem fez ao desenhar a arquitetura tecnológica de funcionamento daquele ambiente para realizar seus desígnios econômicos e invisibilizar seus problemas, em especial a precariedade do trabalho.

Superando o anterior menoscabo (BESSA, 2017) que a doutrina trabalhista atribuía à dependência econômica com sua susten- 
Plataformas digitais e regulação trabalhista: precificação e controle do trabalhador neste novo... Murilo Carvalho Sampaio Oliveira

tação extrajurídica, há cada vez mais autores voltando a aludir a esta teoria. Em 2011, foi apresentada uma proposta de ressignificação da dependência econômica (OLIVEIRA: 2012) a partir dos fundamentos socioeconômicos do trabalho assalariado e não das circunstâncias epidérmicas (e consequenciais) que constavam na tradição de Paul Cuche, Alexandre Zinguerevitch, Dorval Lacerda e José Martins Catharino.

Rogers (2016) debate a mesma questão a partir do princípio da anti-dominação (anti-domination principle) como fundamento axiológico para a aplicação de direitos trabalhistas quando houver na relação a dependência econômica e uma desigualdade na negociação ("economic dependence" and "unequal bargaining power"). Bem na tradição política-histórica norte-americana de liberdade individual, o princípio da anti-dominação é a defesa dos sujeitos contra eventual poder de dominação de outros, haja vista que a legítima liberdade pressupõe a não sujeição à arbitrariedade de outrem.

Em Israel, Davidov (2017), então, reabilita o critério da dependência econômica, sugerindo que os trabalhadores em estado de dependência, ainda que sem subordinação, sejam destinatários da proteção. Cuidando do caso da Uber, Davidov identifica ali um sistema de trabalho com desvantagem sistemática ("systematic disadvantage") que gera vulnerabilidade do condutor. A assimetria decorre: da fixação unilateral do preço da viagem que, consequentemente, significa estipular o lucro deste; do monitoramento constante de seus motoristas; do controle via sistema de classificação e exclusão; e da inserção total destes na organização empresarial da plataforma de transporte, feito em nome da Uber.

Na França, Dockès (2020, p. 181) assevera que há forte dependência - no sentido de fraqueza e submissão - no trabalho em plataformas, pois é esta quem gerencia o próprio mercado de trabalho ao organizar e distribuir as demandas entre os trabaIhadores cadastrados. Entretanto, ressalta que essa dependência não é total, porque nesse modelo as plataformas não exigem a exclusividade do trabalhador. Countouris (2019) relata que o in- 
Plataformas digitais e regulação trabalhista: precificação e controle do trabalhador neste novo... Murilo Carvalho Sampaio Oliveira

teresse doutrinário sobre a dependência econômica é renovado, em razão de sua serventia para a identificação da relação em emprego especialmente nas plataformas, nas quais a expressão "economicamente dependente" retrata adequadamente aqueles trabalhadores.

Compreendendo essas circunstâncias de controle indireto, irrelevância da fiscalização de jornada apenas para fins de verificação de vínculo de emprego, precificação e apropriação, a dependência econômica se apresenta como critério útil para identificar a relação de emprego no caso do trabalho em plataformas. Pimenta, Porto e Rocha asseveram que, no trabalho sob demanda (on-demand), "a utilização do critério da dependência econômica, ao lado da subordinação jurídica, pode ser extremamente útil para o reconhecimento da existência da relação de emprego" (PIMENTA; PORTO; ROCHA, 2019, p. 47).

A concepção de dependência econômica ora afirmada recoloca, de igual modo, a caracterização de trabalho autônomo não como autonomia operacional de dias e horários de ativação, mas como liberdade econômica de definir o preço do seu trabalho, o que significa, na dinâmica capitalista, estabelecer e se apropriar dos frutos do trabalho, na ideia plena de labor por conta própria.

Esta noção de autonomia econômica pode ser extraída de algumas diversas ordens jurídicas. Na Lei californiana de 2019 (ESTADOS UNIDOS, 2019), ainda que posteriormente inaplicável às plataformas por decisão plebiscitária, o terceiro indício do teste da relação de emprego diz respeito a negócio independente ("The person is customarily engaged in an independently established trade, occupation, or business of the same nature as that involved in the work performed", seguindo a racionalidade do caso Dynamex de 2018.

Pimenta, Porto e Rocha asseveram que autonomia concerne a atuar como empresário, no sentido de decidir sobre compras de bens e serviços para a organização e funcionamento do empreendimento e as vendas dos bens produzidos. Esta real liberdade eco- 
Plataformas digitais e regulação trabalhista: precificação e controle do trabalhador neste novo... Murilo Carvalho Sampaio Oliveira

nômica para decidir é que torna legítima a imposição dos lucros e prejuízos ao trabalhador autônomo. Nesta acepção, é o conceito de autonomia que ganha contornos restritos e bem caracterizados, remanescendo um campo de incidência mais amplo para o conceito de trabalho dependente: "é empregado aquele que não atua como empresário, isto é, que não é autônomo." "(PIMENTA; PORTO; ROCHA, 2019; p. 68). Assim, a autonomia se identifica nos indícios de criar sua própria atividade e não ser inserido na organização alheia, apropriar-se dos frutos do trabalho e, por consectário, do seu autogoverno assumir os riscos econômicos de suas escolhas.

\section{Crítica e Uso da Dependência Econômica}

Caracterizada a autonomia por uma feição econômica, por conseguinte, pela oposição à ideia de dependência econômica, é oportuno então percorrer argumentos de crítica à ideia defendida aqui. De igual modo, é importante, no campo pragmático, verificar como a dependência econômica tem sido utilizada em decisões trabalhistas sobre plataformas.

$\mathrm{Na}$ tentativa de enfraquecer a ideias da dependência econômica no trabalho em plataformas, são contrapostos alguns argumentos na doutrina e jurisprudência. Zipperer (2019, p. 171) afirma que não há proveito econômico da plataforma sobre o trabalhador, tendo em vista que este aufere a grande maioria do rendimento de que a precificação alheia. No segundo julgado do TST sobre no caso da empresa Uber (BRASIL, 2018), a decisão negou o vínculo, valendo-se de um argumento secundário de que a relação mais se amoldava a uma parceria, diante do alto percentual de ganho do trabalho que se situa acima de $70 \%$ do proveito econômico do trabalho. 
Plataformas digitais e regulação trabalhista: precificação e controle do trabalhador neste novo... Murilo Carvalho Sampaio Oliveira

Estes argumentos são importantes porque enfrentam o problema pelo viés da análise econômica da relação de trabalho, mas não correspondem à totalidade do fenômeno.

O erro se dá na apuração do resultado econômico bruto como se esse fosse igual ao resultado líquido: quando se quantifica os gastos de aquisição, manutenção e depreciação do veículo, combustível, tributação, ociosidade, despesas com eventuais riscos, tempo de trabalho, entre outros, apura-se que o resultado econômico líquido da plataforma é igual ou superior à parte que auferida pelo trabalhador. O percentual bruto de remuneração se torna materialmente diminuto porque nesse modelo renovado de salário por peça diversos custos da atividade econômica ficam por conta do trabalhador.

Ribeiro e outros (2018) demonstraram que, ao se planilhar a receita bruta com a dedução de despesas de operação (seguro, combustível, lavagem, acesso à internet, alimentação, etc), a depreciação do veículo e a contribuição previdenciária e reserva de continência, o resultado líquido mensal apurado por um motorista da Uber em 2017 em Brasília era um pouco superior ao salário mínimo para uma jornada média de 44 horas semanais. Os autores explicaram que, normalmente, os motoristas apenas subtraem da receita as despesas diretas e imediatas, desconsiderando outras despesas indiretas e a longo prazo, em especial a depreciação do veículo. Do caso estudado, extrai-se os seguintes percentuais: $65 \%$ da receita auferida pelo motorista é com despesas imediatas; a totalidade das despesas diretas e indiretas para a operação do negócio corresponde a $81 \%$ do valor recebido pelo motorista. Com estes números, percebe-se que o trabalhador da empresa Uber aufere, como efetivo lucro, aproximadamente $20 \%$ da receita das viagens, da qual a plataforma já descontou uma média de 25 a $30 \%$. Isto confirma matematicamente que se trata de trabalho expropriado e não de parceria, pois os maiores ganhos e o controle da atividade estão com a plataforma.

No Inquérito Civil do Ministério Público do Trabalho em face da Uber, o gerente geral da empresa no Rio de Janeiro no período 
Plataformas digitais e regulação trabalhista: precificação e controle do trabalhador neste novo... Murilo Carvalho Sampaio Oliveira

de 2015-16 confirma que a Uber dirigia economicamente a relação com o motorista por meio de sua política de precificação, inclusive de modo a impor uma renda em valor aproximado ao salário mínimo, conforme o seguinte trecho do depoimento:

[...] que a Uber sempre teve a preocupação de prestar o serviço de forma barata; que há um time de precificação global na matriz; que a cidade realiza planilha propondo determinado preço, que deve ser aprovado pelo Presidente Global; que a planilha leva em conta distância, número de viagens por hora, trânsito, salário mínio, combustível e o valor do carro e respectiva depreciação; que também é comparada a tarifa com as praticadas pelos táxis; que quanto mais barato, mais o negócio cresce; que a matriz fez pressão no final do ano passado para baixar os preços; que seria a segunda baixa de tarifa do Uber $\mathrm{X}$; que realizou nova planilha, em que modificou o tipo do carro, de FIT para Logan, além de dados de eficiência da cidade, baixando o preço entre 10 a 15\%; que o salário mínimo era calculado por hora, com base em 44 horas semanais; que a remuneração do motorista era calculada entre 1.2 e 1.4 salários mínimos, descontando todos os custos (INQUÉRITO CIVIL, 2016).

Outra crítica oposta é que a precificação alheia é expediente comum em diversas atividades, a exemplo da tarifa de táxi, não se caracterizando por si uma situação de relação empregatícia. Da raiz dessa objeção, é preciso extrair que só precifica quem tem poder capaz de assujeitar os compradores àquele preço. No caso da "bandeirada" do táxi, essa tarifa pública fundamenta-se no poder regulatório, ínsito ao Direito Administrativo, de dispor sobre serviços de utilidade pública, isto é, cuida-se de precificação estatal baseada no interesse com o objetivo (DIAS, 2007) de equacionar o valor razoável para a correlação oferta e disponibilidade do serviço.

Noutro giro, afirma-se que em muitas plataformas digitais o trabalhador é proprietário dos meios de produção, o qual seria um veículo (automóvel, motocicleta ou bicicleta) em atividades pre- 
Plataformas digitais e regulação trabalhista: precificação e controle do trabalhador neste novo... Murilo Carvalho Sampaio Oliveira

senciais sob demanda ou apenas dispositivo informático (celular ou computador) em microtarefas executadas em rede ("on line"). No caso da Uber, Davidov (2017, p. 38) comenta que a propriedade do veículo poderia ser entendida como sinal de independência econômica e de que este sujeito proprietário poderia assumir os riscos do negócio, pois haveria certo controle sobre aquele ativo e o poder definir como utilizá-lo.

Novamente, a superficialidade deste raciocínio é evidenciada quando se compara a expressão econômica do valor de um veículo com a da rede tecnológica que forma a plataforma digital. Diante da totalidade econômica de uma plataforma, percebe-se que um veículo ou computador, por mais caro que seja, é, em termos de valor, insignificante, o que the atribui o papel de mero instrumento de trabalho. Ademais, esta diminuta propriedade sobre os instrumentos de trabalho não permite um agir autonomamente (CASTRO, 2020, p. 204) diante da atividade organizada tecnológica para fins de controle pela plataforma.

Além disso, o real meio produtivo é a organização digital da empresa que criou a plataforma, inclusive não se exigindo propriedade destes instrumentos de trabalho, mas apenas sua posse, tendo em vista os diversos sistemas de aluguel ou financiamento com intermediação da própria plataforma. Em outros casos, aceita-se que o trabalhador faça suas entregas a pé, desnudando que o bem vendido pelo obreiro é apenas força de trabalho.

Sobre a assunção dos riscos do negócio, convém situar tal elemento como um consectário do molde econômico da relação. Se há efetiva autonomia, os riscos são daquele que tomou as decisões com sua independência econômica. No entanto, se a relação é manifestadamente assimétrica e a parte empoderada impõe os riscos à hipossuficiente, há claramente um comportamento abusivo advindo da relação de poder existente. No trabalho em plataformas, a simples imposição por estas dos riscos da atividade não significa a caracterização de autonomia, porque haveria primeiro a necessidade de se assegurar liberdade, autodireção e independência econômica para que as perdas desta má-gestão se- 
Plataformas digitais e regulação trabalhista: precificação e controle do trabalhador neste novo... Murilo Carvalho Sampaio Oliveira

jam atribuídas à pessoa que controla realmente o negócio. Como pontuam Pimenta, Porto e Rocha (2020, p. 69): “Tomar decisões empresariais significa ter a chance de ganhar mais dinheiro, mas também o risco de sofrer prejuízos, o que revela que a pessoa trabalha por conta própria".

Outra objeção é a alegação de o trabalhador fica simultaneamente ativado em diversas plataformas, o que impediria então sua fixação com uma destas. Este argumento diz respeito, em verdade, à exclusividade do tomador dos serviços, o qual, tanto a lei como a doutrina, não figura como elemento essencial do vínculo empregatício. Contudo, é necessário enfatizar que, durante o efetivo tempo de trabalho presencial como em entregas ou viagens, não há concomitância de trabalho em duas plataformas, isto é, o trabalho real-concreto não é prestado simultaneamente para duas empresas.

A concomitância de ativação em duas ou mais plataformas se dá no tempo à disposição em espera por viagens, e assim somente ocorre porque tal período não é remunerado pelas plataformas, logo o trabalhador deve, pelo império da necessidade, se ativar ao máximo de plataformas até receber a demanda, a partir de quando trabalha apenas para um tomador. Isto é, esta pluralidade de ativações no momento do aguardo de demandas é um fato advindo da opção do modelo de negócios estipulada pela própria empresa que, a título de não remunerar o tempo à disposição, permite que o trabalhador fique ativado em diversas plataformas.

Esta questão do tempo de ativação remota às críticas vinculadas à eventualidade do trabalho em plataformas. Seguindo a distinção acima entre tempo efetivo de trabalho e tempo de espera à disposição das demandas, é indispensável considerar não apenas o tempo de execução da tarefa, microtarefa ou atividade, mas a totalidade do tempo que o trabalhador vive a esperar por trabalho, para fins de configuração do elemento legal de não-eventualidade, o que não se confunde com o tempo de remuneração pelo tempo à disposição. Isto é, a habitualidade no trabalho em plataformas não deve ser apurada pela duração da tarefa executada, mas pela 
Plataformas digitais e regulação trabalhista: precificação e controle do trabalhador neste novo... Murilo Carvalho Sampaio Oliveira

continuidade do registro do trabalhador naquele ambiente, como propõem Pimenta, Porto e Rocha (2020, p. 97).

Como visto, o poder de precificar as corridas da Uber, inclusive majorando-as pela tarifa dinâmica, é, em verdade a evidência cabal de que esta plataforma dirige a prestação dos serviços em termos econômicos. Ao fixar pequenos valores pelas corridas, ela impõe mais tempo de trabalho aos motoristas; ao transferir as despesas de manutenção e os riscos econômicos o negócio, e simultaneamente continuar definindo o preço final da viagem, a Uber consegue, ao final, fixar em termos médios o padrão remuneratório dos seus motoristas. Neste cenário, conclui Pires que não haveria elementos fáticos para se constatar autonomia no trabalho na empresa Uber, diante da "proeminência as noções de dependência econômica, trabalho por conta alheia e integração à empresa" (PIRES: 2019; p. 168) naquele modelo de trabalho.

\section{Conclusões}

O percurso sociojurídico crítico permitiu examinar o modelo de gestão do trabalho em plataformas digitais como uma renovação do antigo método de salário "por peça", agora de feição tecnológica e assim com mais domínio e controle, além da transferência de uma série de custos e riscos para o trabalhador. No âmbito jurídico, defende-se que a precificação e sua consectária ausência de liberdade econômica representa, por si só, a situação de dependência do trabalhador, a qual deve ser adjetivada como econômica, afim de explicitar seu fundamento extrajurídico. Isto é, quando a plataforma decide precificar o trabalho alheio ela manifesta controle próprio da posição jurídica de empregador.

De igual modo, a perspectiva crítica transpassa as questões tecnológicas que invisibilizam as questões sociais de precariedade da relação socioeconômica de trabalhar por conta alheia. Por isso, deve-se recusar as denominações de aplicativo ou atribuir mais 
Plataformas digitais e regulação trabalhista: precificação e controle do trabalhador neste novo... Murilo Carvalho Sampaio Oliveira

relevância ao algoritmo do que sua a programação feita por decisões humanas com seus interesses econômicos. Ultrapassados esse senso comum tecnológico, o trabalho em plataformas digitais demanda uma urgente necessidade regulatória para tratar as veIhas (assalariamento e assimetria) e as novas (dados como valor e mercadoria) questões.

Portanto, falar em plataformização do trabalho - e não uberização - é pôr em debate o modelo de organização econômica estruturado no meio digital que está em ascensão. É sobretudo retomar o papel do Direito e do Direito Laboral em cumprir o desígnio da Organização Internacional do Trabalho de não permitir que o trabalhador - indissociável do seu trabalho - prossiga recebendo o tratamento de mera mercadoria ("commodity"). Sustentar, enfim, a regulação trabalhista das plataformas digitais dirigentes é, novamente, defender a ontologia e a razão de ser do Direito do Trabalho como instrumento de civilidade e dignidade para o trabalho assalariado.

\section{Referências}

ABÍLIO, Ludmila. Sem Maquiagem: o trabalho de um milhão de revendedoras de cosméticos. Boitempo, São Paulo, 2014.

ABÍLIO, Ludmilla. Uberização do trabalho: subsunção real da viração. Rio de Janeiro. 2017. Disponível em: <http://www.passapalavra.info/2017/02/110685> Acesso em 22-fev-2017.

ADAMS-PRASSL, Jeremias. Gestão algorítmica e o futuro do trabalho. In CARELLI, Rodrigo; CAVALCANTI, Tiago; FONSECA, Vanessa. $O$ futuro do trabalho: Os efeitos da revolução digital na sociedade. Brasília: ESMPU, 2020, p. 85-100.

AMADO, João Leal; SANTOS, Catarina Gomes. A Uber e os seus motoristas: mindthegap! In: CHAVES JÚNIOR, José Eduardo de Resende (Org.) Tecnologias Disruptivas e a Exploração do Trabalho Humano. São Paulo: Ltr, 2017. 
Plataformas digitais e regulação trabalhista: precificação e controle do trabalhador neste novo... Murilo Carvalho Sampaio Oliveira

ANTUNES, Ricardo. O privilégio da servidão. São Paulo: Boitempo, 2018.

ASSIS, Anne; COSTA, Joelane; OLIVEIRA, Murilo. O Direito do Trabalho (des)conectado nas plataformas digitais.

Revista Teoria Jurídica Contemporânea, v. 4, p. 246-266, 2019. Disponível em https://revistas.ufrj.br/index.php/rjur/article/ download/24367/17785.

BESSA, Cesar. Além da Subordinação Jurídica no Direito do Trabalho. São Paulo, LTr, 2017.

BRASIL. Tribunal Superior do Trabalho. Vínculo de emprego. Motorista. Uber. Ausência de subordinação. $\mathrm{n}^{\circ}$ TSTAIRR-11199-47.2017.5.03.0185. Relatora: Ministra Dora Maria da Costa. Brasília: DEJT, 18 dez. 2018.

BRASIL. Tribunal Superior do Trabalho. Vínculo de emprego. Motorista. Uber. Ausência de subordinação. n RR - 100012389.2017.5.02.0038. Relator: Ministro Breno Medeiros. Brasília: DEJT, 07 fev. 2020. p. 1-25.

CALDAS, Josiane. A Economia Compartilhada e a Uberização do Trabalho: utopias do nosso tempo? Porto Alegre, RS: Editora Fi, 2020.

CARELLI, Rodrigo de Lacerda. O Caso Uber e o Controle porProgramação: de carona para o Século XIX. In: CHAVES JÚNIOR, José Eduardo de Resende (Org.). Tecnologias Disruptivas e a Exploração do Trabalho Humano. São Paulo: Ltr, 2017.

CARELLI, Rodrigo de Lacerda. O Mundo do Trabalho e os Direitos Fundamentais: O Ministério Público do Trabalho e a Representação Funcional dos Trabalhadores. 1. ed. Porto Alegre: Sergio Fabris, 2011.

CARELLI, Rodrigo Lacerda. Formas atípicas de trabalho. São Paulo: LTr, 2004.

CASTELLS, Manuel. A sociedade em rede. 14. ed., rev. e atual. São Paulo: Paz e Terra, 2011. 
Plataformas digitais e regulação trabalhista: precificação e controle do trabalhador neste novo... Murilo Carvalho Sampaio Oliveira

CASTRO, Viviane Vidigal de. As ilusões da uberização: um estudo à luz da experiência de motoristas Uber. 2020. f. 303. Dissertação (Mestrado em Filosofia) - Universidade Estadual de Campinas, Instituto de Filosofia e Ciências Humanas, Campinas, 2020, SP.

CHERRY, Miriam A., People Analytics and Invisible Labor (July 18, 2017). Saint Louis University Law Journal, 61, 1, 2016-2017. Available at SSRN: https://ssrn.com/abstract=3004797

COLLI, Juliana Marília. O ‘salário por peça' e sua reposição nas novas formas de trabalho à fação. Estudos de Sociologia, Araraquara, v. 3, n. 5, p. 75-86, 2008. Disponível em: https://www. researchgate.net/publication/268361593_o_'salario_por_peca'_e_ sua_reposicao_nas_novas_formas_de_trabalho_a_facao. Acesso em: 28 nov. 2020.

COUNTOURIS, Nicola. La gouvernance par les algorithmes et le récit alternatif du travail. In SUPIOT, Alain. (dir) Le travail au XXe siècle. Paris: Les éditions de l'atelier, 2019.

DARDOT, Pierre; LAVAL, Christian. A nova razão do mundo. São Paulo: Boitempo, 2016.

DAVIDOV, Guy. The Status of Uber Drivers: A Purposive Approach. Spanish Labour Law And Employment Relations Journal, [s.I.], v. 6, n. 1-2, p.6-15, 6 nov. 2017. Universidad Carlos III de Madrid. http://dx.doi.org/10.20318/sllerj.2017.3921.

DE STEFANO, Valerio De. Automação, inteligência artificial e proteção laboral: patrões algorítmicos e que fazer com eles. In: CARELLI, Rodrigo; CAVALCANTI, Tiago; FONSECA, Vanessa. 0 futuro do trabalho: Os efeitos da revolução digital na sociedade. Brasília: ESMPU, 2020, p. 21-64.

DE STEFANO, Valerio. The rise of the "just-in-time workforce": on-demand work, crowdwork and labour protection in the "gig-economy". International Labor Office, Inclusive Labour Markets, Labour Relations and Working Conditions Branch, 
Plataformas digitais e regulação trabalhista: precificação e controle do trabalhador neste novo... Murilo Carvalho Sampaio Oliveira

Conditions of work and employment series, n. 71, Geneva, 2016. Disponível em: http://www.ilo.org/wcmsp5/groups/public/---ed_ protect/---protrav/---travail/documents/publication/wcms_443267. pdf. Acesso em: 18 mar. 2020.

DELEUZE, Gilles. Post - Scriptum sobre as Sociedades de Controle. Conversações. Rio de Janeiro, 1990. Pgs 219-226. Disponível em https://edisciplinas.usp.br/mod/resource/view. php?id=41105. Acesso em 01 mar 2020.

DIAS, Flavio Augusto de Oliveira Passos. Serviços de táxi: elementos para um novo modelo regulatório. 2007. 98 f. Dissertação (Mestrado em Transportes). Universidade de Brasília, Brasília, 2007.

DOCKÈS, Emmanuel. Os empregados das plataformas. In: CARELLI, Rodrigo; CAVALCANTI, Tiago; FONSECA, Vanessa. o futuro do trabalho: Os efeitos da revolução digital na sociedade. Brasília: ESMPU, 2020.

\section{DUBAL, Veena. The Time Politics of Home-Based Digital}

Piecework. Ssrn Electronic Journal, [S.L.], p. 1-17, 2020. Elsevier BV. http://dx.doi.org/10.2139/ssrn.3649270. Disponível em: https://www.researchgate.net/publication/343125177_The_Time_ Politics_of_Home-Based_Digital_Piecework. Acesso em: 21 dez. 2020.

ESTADOS UNIDOS. Ab-5 Worker Status: Employees And Independent Contractors: Assembly Bill No. 5. Disponível em: https://leginfo.legislature.ca.gov/faces/billTextClient.xhtml?bill_ id=201920200AB5. Acesso em: 18 dez. 2020.

\section{FIGUEIRAS, Vitor; CALVALCANTE, Sávio. 0 trabalho no século} XXI e o novo adeus à classe trabalhadora. Princípios, [S.L.], v. 1, n. 159, p. 11-41, 2020. Editora Cubo. http://dx.doi.org/10.4322/ principios.2675-6609.2020.159.001. Disponível em: https://revistaprincipios.emnuvens.com.br/principios/article/view/19. Acesso em: 23 nov. 2020. 
Plataformas digitais e regulação trabalhista: precificação e controle do trabalhador neste novo... Murilo Carvalho Sampaio Oliveira

FIGUEIRA, Vitor; CALVALCANTE, Sávio. O trabalho no século XXI e o novo adeus à classe trabalhadora. Princípios, [S.L.], v. 1, n. 159, p. 11-41, 2020. Editora Cubo. http://dx.doi.org/10.4322/ principios.2675-6609.2020.159.001. Disponível em: https://revistaprincipios.emnuvens.com.br/principios/article/view/19. Acesso em: 23 nov. 2020.

FONSECA, Maria Guadalupe Piragibe. Iniciação à pesquisa no direito: pelos caminhos do conhecimento e da invenção. Rio de Janeiro: Elsevier 2009.

FONTES, Virgínia. Capitalismo em tempos de uberização: do emprego ao trabalho. Revista do Niep - Marx, Niterói, v. 5, n. 8, p. 45-67, jul. 2017. Disponível em: http://www.niepmarx.blog.br/ revistadoniep/index.php/MM/article/view/220. Acesso em: 04 jun. 2020.

GROHMANN, Rafael. Plataformização do trabalho: entre dataficação, financeirização e racionalidade neoliberal. Revista Eptic, São Cristóvão, SE, v. 21, n. 1, p. 106-122, 2020. Disponível em https:// revec.revistas.ufs.br/index.php/eptic/article/view/12188. Acesso em 16 dez 2020.

GUANAIS, Juliana Biondi. Salario por pieza y superexplotación del trabajo. Sociología del Trabajo, [S.L.], n. 92, p. 67-85, 12 abr. 2018. Universidad Complutense de Madrid (UCM). http://dx.doi. org/10.5209/stra.59579. Disponível em: https://recyt.fecyt.es/index.php/sociologiatrabajo/article/view/64289. Acesso em: 3 nov. 2020.

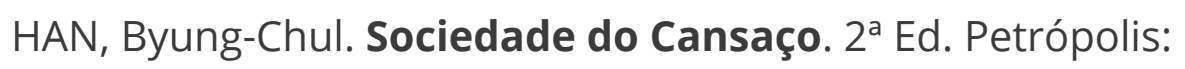
Vozes, 2020.

INQUÉRITO CIVIL n. ${ }^{\circ}$ 1417.2016.01.000/6 da PROCURADORIA REGIONAL DO TRABALHO DA $1^{\circ}$ REGIÃO, p. 214.

DIAS, Flavio Augusto de Oliveira Passos. Serviços de táxi: elementos para um novo modelo regulatório. 2007. 98 f. Dissertação (Mestrado em Transportes). Universidade de Brasília, Brasília, 2007, p. 55. 
Plataformas digitais e regulação trabalhista: precificação e controle do trabalhador neste novo... Murilo Carvalho Sampaio Oliveira

KALIL, Renan. A regulação do trabalho via plataformas digitais. São Paulo: Blucher, 2020.

LAZZARATO, Maurizio. La fábrica del hombre endeudado. Ensayo sobre la condición neoliberal. Buenos Aires: Amorrortu, 2013.

LAZZARATO, Maurizio. Revolução ou fascismo? O neoliberalismo em chave estratégica. São Paulo: n-1 edições, 2019.

LOCKE, Jonh. Segundo Tratado sobre o Governo. 2. ed. In: Os pensadores. Tradu-ção de Anoar Aiex e E. Jacy Monteiro. São Paulo: Abril Cultura, 1978, p. 45-46.

MARX, Karl O Capital: Crítica da Economia Política. Livro I: O Processo de Circulação do Capital, Sâo Paulo, Boitempo, 2009.

MAZZOTTI, Massimo. Algorithmic life. In: PRIDMORE-BROWN, Michele; CROCKETT, Julien. The digital revolution: debating the promises and perils of the Internet, automation, and algorithmic lives in the last years of the Obama Administration. Los Angeles: Los Angeles Review of Books: 2017, p. 31-39

MINAS GERAIS. $12^{\text {a } V a r a ~ d o ~ T r a b a l h o ~ d e ~ B e l o ~ H o r i z o n t e . ~ S e n t e n c ̧ a ~}$ no processo nº 0010497-38.2017.5.03.0012. Belo Horizonte, 2017.

MINAS GERAIS. 34 ${ }^{\text {a }}$ Vara do Trabalho de Belo Horizonte. Sentença no processo $n^{\circ}$ 0011098-61.2019.5.03.0113. Belo Horizonte, 2020.

OLEA, Manoel Alonso. Introdução ao Direito do Trabalho. 2. ed. Porto Alegre: Sulina, 1969.

OLIVEIRA, Murilo Carvalho Sampaio; CARELLI, Rodrigo de Lacerda; GRILLO, Sayonara. Conceito e crítica das plataformas digitais de trabalho. Revista Direito e Práxis, [S.L.], v. 11, n. 4, p. 2609-2634, dez. 2020. http://dx.doi.org/10.1590/21798966/2020/50080. Disponível em: https://www.e-publicacoes.uerj. br/index.php/revistaceaju/article/view/50080. Acesso em: $10 \mathrm{dez}$. 2020. 
Plataformas digitais e regulação trabalhista: precificação e controle do trabalhador neste novo... Murilo Carvalho Sampaio Oliveira

OLIVEIRA, Murilo. A ressignificação da dependência econômica. Revista eletrônica: acórdãos, sentenças, ementas, artigos e informações. Porto Alegre, RS, v. 8, n. 135, p. 58-78, mar. 2012. Disponível em: https://hdl.handle.net/20.500.12178/30176. Acesso em: 28 jan. 2020.

OLIVEIRA, Murilo. Relação de emprego, dependência econômica e subordinação jurídica: revistando os conceitos. 2a ed. Curitiba: Juruá, 2019.

PARAÍBA. Tribunal Regional do Trabalho da $13^{\mathrm{a}}$ Região. Acórdão em Recurso Ordinário. Processo nº 0000699-64.2019.5.13.0025. Relator: Desembargador Thiago Andrade. João Pessoa: 2020.

PIMENTA, José Roberto Freire; PORTO, Lorena Vasconcelos; ROCHA, Cláudio Jannotti da. A dependência econômica como critério identificador da relação de emprego. Revista de direito do trabalho, São Paulo, SP, v. 45, n. 206, p. 19-44, out. 2019.

PIMENTA b, José Roberto Freire; PORTO, Lorena Vasconcelos; ROCHA, Cláudio Jannotti da. A dependência econômica e a subordinação jurídica como critérios identificadores da relação de emprego. Belo Horizonte: Editora Virtualis, 2019.

PIMENTA, José Roberto Freire; PORTO, Lorena Vasconcelos; ROCHA, Cláudio Jannotti da. A dependência econômica como critério identificador da relação de emprego. In: ROCHA, Cláudio Jannotti da; PORTO, Lorena Vasconcelos (org). O Mundo do Trabalho e a $4^{\text {a }}$ Revolução Industrial. São Paulo: Tirant Lo blanch, 2020.

PIRES, Elisa Guimarães Brandão. Aplicativos de transporte e o controle por algoritmos: repensando o pressuposto da subordinação jurídica. 2019. Dissertação (mestrado) - Universidade Federal de Minas Gerais, Faculdade de Direito: Belo Horizonte, 2019.

PORTUGAL. Lei ${ }^{\circ} 45$, de 10 de agosto de 2019. Regime jurídico da atividade de transporte individual e remunerado de passa- 
Plataformas digitais e regulação trabalhista: precificação e controle do trabalhador neste novo... Murilo Carvalho Sampaio Oliveira

geiros em veículos descaracterizados a partir de plataforma eletrónica. Lisboa: Diário da República, 10 ago. 2018. "Lei Uber". Disponível em: https://dre.pt/home/-/dre/115991688/details/maximized. Acesso em: 22 jun. 2020.

PROJETO DE LEI N 3887/2020. (2020). Institui a Contribuição Social sobre Operações com Bens e Serviços - CBS, e altera a legislação tributária federal. Fonte: https://www.camara.leg.br/ proposicoesWeb/prop_mostrarintegra?codteor=1914962.

RIBEIRO, Érica; OLIVEIRA, Murilo. Promessas de liberdade e estratégias de controle: crítica às condições de trabalho dos motoristas da Uber. Artigo no prelo. 2021.

RIBEIRO, H. A. S e outros. Uber: Transporte para complementação de renda. Brasília, 2018. Disponível em:<https://www.researchgate.net/profile/Hugo_Ribeiro27/publication/326160920_Uber_ transporte_para_complementacao_de_renda/links/5b3bdfa5a6fdcc8506eebf24/Uber-transporte-para-complementacao-de-renda. pdf> Acesso em: 18 nov 2020.

RIO DE JANEIRO. $75^{a}$ Vara do Trabalho do Rio de Janeiro. Sentença no processo ${ }^{\circ}$ 0100351-05.2017.5.01.0075. Rio de Janeiro, 2018.

ROGERS, Brishen. Employment rights in the platform econmy: getting back to basics. Policy Review 681, v. 10, p. 500505, 2016. Harvard Law and. Disponível em: https://harvardlpr.com/wp-content/uploads/sites/20/2016/06/10.2_7_Rogers.pdf Acesso em: 17 nov. 2020.

ROUVROY, Antoniette; BERNS, Thomas. Governamentalidade algorítimica e perspectivas de emancipação: o díspar como condição de individuação pela relação?. In: BRUNO, Fernanda et al. Tecnopolíticas de vigilância: perspectivas da margem. Perspectivas da margem. São Paulo: Boitempo, 2018. p. 107-140.

SÃO PAULO. $8^{\text {a }}$ Vara do Trabalho de São Paulo. Sentença no processo no 1001058-88.2018.5.02.0008. Belo São Paulo, 2019. 
Plataformas digitais e regulação trabalhista: precificação e controle do trabalhador neste novo... Murilo Carvalho Sampaio Oliveira

SCHWAB, Klaus. A Quarta Revolução Industrial. São Paulo: Edipro. 2016.

SILVA, Sayonara Grillo Coutinho Leonardo da. Duas notas sobre novas tutelas laborais no multifacetado desenho do mundo do trabalho contemporâneo. Revista do Tribunal Superior do Trabalho, Porto Alegre, RS, v. 74, n. 3, p. 121-148, jul./set. 2008.

SILVA, Tiago Falchetto. Elemento regulador do ciberespaço, o código-fonte, e-discovery e o contrato-realidade virtual na sociedade da informação. In: LEME, Ana Carolina Reis Paes; RODRIGUES, Bruno Alves; CHAVES JÚNIOR, José Eduardo de Resende (Org.).

Tecnologias Disruptivas e a Exploração do Trabalho Humano. São Paulo: Ltr, 2017. p. 323-329.

SLEE, Tom. Uberização: A Nova Onda do Trabalho Precarizado. Tradução: João Peres.São Paulo: Elefante, 2017.

SRNICEK, Nick. Capitalismo de plataforma. Trad. Aldo Giacometti. Ciudad Autónoma de Buenos Aires: Caja Negra, 2018. STONE, Brad. As Upstarts: Como a Uber, o Airbnb e as Killer Companies do Novo Vale do Silício Estão Mudando o Mundo. Rio de Janeiro: Intrínseca, 2017.

SUPIOT, Alain. Crítica do direito do trabalho. Lisboa: Fundação Calouste Gulbenkian, 2016.

UBER. Termos e condições gerais dos serviços de intermediação digital. Disponível em https://www.uber.com/legal/en/document/?name=general-terms-of-use\&country=brazil\&lang=pt-br. Acesso em 05 mai 2020.

VALLAS, Steve; SCHOR, Juliet. What Do Platforms Do? Understanding the Gig Economy. Annual Review of Sociology V 46, N 1. 2020. Disponível em https://www.annualreviews.org/ doi/abs/10.1146/annurev-soc-121919-054857. Acesso em 05 mai 2020. 
Plataformas digitais e regulação trabalhista: precificação e controle do trabalhador neste novo... Murilo Carvalho Sampaio Oliveira

WOLFF, Simone. "trabalho informacional" e a reificação da informação sob os novos paradigmas organizacionais. In: ANTUNES, Ricardo; BRAGA, Ruy (Orgs.). Infoproletários: degradação real do trabalho virtual. São Paulo: Boitempo, 2009, pgs. 89-112.

WOLFF, S. As Startups na perspectiva das cadeias globais de valor: financeirização dos trabalhos de inovação e a reinvenção do salário por peça. REVISTA DE CIÊNCIAS SOCIAIS POLÍTICA \& TRABALHO, v. 51, p. 90-107, 13 maio 2020.

ZIPPERER, André. A intermediação de trabalho via plataformas digitais. São Paulo: LTr, 2019. 